\title{
SOCIOLOGICAL STUDY OF HARMONY IN DIVERSITY: LESSONS FROM SALATIGA
}

\author{
ANDIKA DWIARTA PUTRA*, DARU PURNOMO, \\ ALVIANTO WAHYUDI UTOMO \\ Universitas Kristen Satya Wacana, Salatiga
}

\section{Abstract}

Salatiga is known for its diversity as there are more than 33 tribes living harmoniously together in this city. The existence of two religious-based education institutions, i.e. Universitas Kristen Satya Wacana and Institut Agama Islam Negeri Salatiga further proves the diversity of this city that already exists. Moreover, Salatiga respectively gained the predicate as the most top 10 tolerant cities in Indonesia within three years from a Non-Governmental Organization (NGO) that promotes tolerance. Based on functional-structural paradigm, society is assumed to be an organic system that has relationships among its parts to maintain the existing system. This study uses the constructivism approach with qualitative methods. The harmony established by CSOs, NGOs, the Government, and religious leaders through programs or activities is aimed to provide motivation and encouragement to the community or society so that they are able to maintain harmony amidst the diversity in Salatiga. Yet, it does not mean that there are no problems or obstacles threating this harmony such as the acts of radicalism from the groups originating from outside Salatiga. The radical groups are trying to mess the tolerance and harmony that has been established for a long time in Salatiga.

Salatiga dikenal dengan keberagamannya, karena didalam Kota Salatiga terdapat lebih dari 33 suku dimana hidup harmonis secara

\footnotetext{
* Corresponding author: Jl. Diponegoro No.52-60, Sidorejo, Salatiga, Indonesia, 50711. E-mail: andiarta.adp@gmail.com.
} 
bersamaan. Hal ini turut didukung dengan hadirnya dua lembaga pendidikan berbasis agama yakni Universitas Kristen Satya Wacana dan Institut Agama Islam Negeri Salatiga menambah keberagaman yang ada. Terlebih, Salatiga sudab mendapatkan predikat sepulub besar kota paling toleran sebanyak tiga kali berturut-turut dari sebuah Lembaga Swadaya Masyarakat yang mempromosikan toleransi. Berdasarkan paradigma fungsional-struktural, masyarakat diasumsikan sebagai sistem organik yang memiliki hubungan antar bagiannya untuk mempertahankan sistem yang ada. Dalam penelitian ini, menggunakan pendekatan konstruktivisme dengan metode kualitatif. Harmonisasi yang dibangun oleh $\mathrm{Or}$ mas, LSM, Pemerintah, serta tokoh agama melalui program atau kegiatan bertujuan untuk memberikan motivasi tersendiri serta dorongan sikap kepada masyarakat agar tetap menjaga harmonisasi di tengah keberagaman yang dimiliki Salatiga. Kendati demikian, bukan berarti tidak dijumpai masalah atau halangan yang mengancam harmonisasi. Seperti radikalisme yang berasal dari luar Salatiga, ataupun kelompok radikal yang berusaha menghancurkan sikap toleransi dan harmonisasi yang sudah terbangun di masyarakat Salatiga.

Keywords: community harmony; diversity practice; Salatiga; sociological study; tolerance.

\section{Introduction}

Setara Institute annually conducts surveys on the index of Tolerant Cities in 94 cities in Indonesia. Based on the results of the survey conducted in 2018, Singkawang City was the most tolerant city, followed by Salatiga, Pemantang Siantar, Manado, Ambon, Bekasi, Kupang, Tomohon, Binjai, and Surabaya (Setara 2018). Through this survey, it is expected that other cities in Indonesia, especially those that have not received a tolerant predicate, would compete to promote tolerance, so that peaceful conditions can be realized. However, many cases of intolerance still occur in Indonesia. For example, on 5 October 2017, there 
was a demonstration to the construction of Santa Laurensia Suvarna Padi school, in Sindang Jaya, Tangerang Regency, even though the foundation has pocketed building permission from the government of Tangerang Regency. In fact, the permit has been given but radical groups still refused the establishment of the Santa Laurensia school. The freedom to embrace religion and establish a school or place of worship seems to be very difficult to do in this country, especially to preserve "local" religion such as kejawen. Like the case reported by CNN Indonesia, on Friday 1 June 2017 (Gumilang 2017) that Engkus Ruswana has nothing to do when his mother's body was refused to be buried in Ciamis, West Java by the locals just because Engkus and his family believed in their ancestor's religion. With many cases of intolerance, it becomes a challenge for a City or Regency in Indonesia to compete to be a tolerant City for the realization of peace and security in society.

Some studies with regard to tolerance among others were conducted by Hermawati, Paskarina, and Runiawati (2017), Mutiara (2017), and Faridah (2013). Hermawati, Paskarina, and Runiawati (2017) focused on measures of tolerance in the city of Bandung. Mutiara (2017) focused on interfaith communities and north Java seashore beliefs, which are well known for their intimacy ties. Meanwhile, Faridah (2013) focused on tolerance in Penambongan housing. The three aforesaid studies only discussed the interactions that led to tolerance among the people. However, they have not talked about conflict resolution due to intolerant behavior. But it is found in the researches conducted by Utama and Samiyono. Utama (2015) focused on the relationship between faith and religiosity and tolerance behavior. Meanwhile, Samiyono (2011) found that conflict can be reduced with efforts made by the government by building and developing pluralism. However, the studies conducted by both 
of them have not discussed the interaction among community towards harmonization.

The studies focusing on the issue of harmony in diversity actually have been carried out. Haryanto (2012) conducted a study on the interaction and harmony of the people in Singkawang City where people still interact as a cosmopolitan community. Purba (2015) found the factors that influenced the creation of peace because of the existence of Christianity and Islam that drove to love one another amid the differences in the communities. Still, these studies have not deeply viewed the interaction among religious communities in order to achieve harmony in a region. Therefore, there is still an opportunity to examine the harmony by which interactions can be carried out in the middle of diversity and the management of conflicts which leads to harmony in a pluralistic society. From the authors observations, it is found that the forms of diversity practices are still existing in the plural community of Salatiga City so that this city was given the title of tolerant city. To examine this, the authors used the theory of AGIL (Adaptation, Goal Attainment, Integration, and Latency) of Functional Structures from Talcott Parsons as an analysis tool.

Parson argues that society is composed of a different set of subsystems based on the structure and function owned by every element in the society. When the society is changed, generally people will grow with better abilities than before in dealing with and overcoming problems in their lives. It can be said that Parson belongs to the group that sees optimism in a process of change (Ritzer 2014, 257). In structural-functional theory, there is a component of AGIL which can be explained as follows; Adaptation is a system of actions that has a function of adaptation by adjusting and transforming or changing the external world. While the Goal Attainment carries out the function of achieving goals by defining or setting goals of the system and mobilizing 
resources to achieve them. The Integration function is carried out by the social system by controlling its components. Finally, the Latency system works by providing norms or values for actors who motivate them to act (Ritzer 2008, 257)

In this study, the authors use the qualitative approach. Data collection techniques used are observation, documentation and in-depth interviews. In-depth interviews were conducted with CSOs (Community Organizations), NGOs (Non-Governmental Organizations), community leaders, religious leaders, ethnic associations and Salatiga community members. Data analysis techniques follow the stages of collecting data. After the data were collected, the authors performed data reduction, data presentation, verification, and made a conclusion.

\section{The Overview of Community Tolerance in Salatiga City}

In measuring the value of the Tolerant City Index (TCI), it is equivalent to using a negative right approach. The TCI also checks and monitors the positive actions of the City Government in promoting and building tolerance and pluralism both through government policies such as regional mid-term development plan (RPMJD), official statements, responses to events, and through the establishment of a culture of tolerance in the society. Setara Institute applies several variables of tolerance in the city that influence social behavior between the identities and entities of the city's residents. The city must have several criteria as follows: (1) The city government has regulations that are conducive to practice and promotes tolerance, both in the form of planning and implementation. (2) The statements and actions of the city government apparatus are conducive to practice and they also promote tolerance. (3) In the city, violations against beliefs/religious freedom are low. (4) The city shows sufficient effort in controlling the diversity of the religious identity of its citizens. 
This study uses four parameters of measurement by adopting the measurement framework introduced by Grim and Finke, namely: (1) City Government Regulation (RPJMD and discriminatory policy); (2) Government Actions (statements and actions related to events) (3) Social Regulation (violation events); (4) Religious Demographics (population composition based on religion)

The parameter set by Setara for assessment is the government's performance in creating tolerant social conditions through policies addressed to the community. In other words, the government of Salatiga city actually has been able to establish good conditions through the policies that they made. For example, in 2018, Salatiga were recorded to have 167 CSOs and NGOs registered in the National Unity and Politics Agency (Bakesbangpol) of Salatiga City. The CSOs and NGOs registered in Bakesbangpol were about $70 \%$. They are mostly Religion and Culture-based NGOs and CSOs. While about 30\% were mass movement or hobby organizations. Ambar, as a staff member of the Percik NGO of Salatiga, stated that the synergy and relationships between the government of Salatiga City and NGOs or among NGOs with regard to the increasing of tolerance have been established for a long time and it is maintained. It is evidenced by the programs or activities carried out in collaboration with NGOs and CSOs.

One of the programs is halaqah. Halaqah is an activity to increase nationalism perception which is aimed to facilitate organizations and NGOs in organizing organizations, Encouraging CSOs and NGOs to organize national insight development activities in Salatiga City, establishing good partnerships among mass organizations, and NGOs with the Salatiga City Government ${ }^{3}$.

${ }^{2}$ Halaqah means circle. The word halqah min al-nās means a group of people sitting in a round (A. W. Munawwir 2002, 290)

${ }^{3}$ The report of Halaqah activity from Political and National Unity Agen- 
There are so many parties involved in these activities not only Harmony Forum of Religious People (FKUB) but also most of the parties that struggle for tolerance. Halaqah is only one of the government programs or a program of Kesbangpol of Salatiga City in collaborating with NGOs and CSOs to promote tolerance. There are still many events or programs held by Kesbangpol in promoting tolerance such as the hearings between Forkominda (Regional Leadership Communication Forum) with religious leaders, Socialization of Religious Harmony (FKUB), Improvement tolerance seminars, Outbound of tolerant youth, Culture Carnival, Cross Faith Camps organized by Percik NGO with some Churches and Islamic Boarding Schools which was the participants were not only from NGOs or related CSOs, but also students, college students as well as the community widely. Some of the above activities are initiated by the government to build tolerance within a society. Then it is also necessary to know how people adapt to different environments. Adaptation is a system that deals with urgent situational external needs. The system must adapt to its environment and vice versa the environment needs to adapt to its needs (Ritzer 2012, 409)

\section{Community Harmony Amidst Diversity in Salatiga City}

\section{Community Adaptation}

In the adaptation process, acceptance of the presence of a new system is needed so that the system can fulfill its needs. In the adaptation process, of course, it would be either successful or unsuccessful so that it is difficult to fulfill the necessary needs. This was experienced by Mr. Nyoman as a Hindu Mangku of Adya Dharma Temple at Bendosari Hamlet, Kumpulrejo Village, Argomulyo Sub-District, Salatiga City. The neighborhood of the temple, which is predominantly Christian, can accept the presence of the temple that has already existed since 1971. But

cy of Salatiga City in 2017 (Kesbangpol Salatiga 2017) 
the presence of this temple was not easily accepted by the surrounding community. A process of adaptation was carried out by Mr. Nyoman as a migrant and as Mangku of Hindu religion by means of interaction intensely with the community through visitation and food delivery every time the worship is held.

The existential interpretation is the ability of a person to see himself exists in his environment (Hamilton 1983). It was practiced by Mr. Nyoman so that the temple could exist and accepted by the surrounding community through interactions which is always built amidst the community. Likewise, the community have to adapt to the presence of Pura amid their social environment. It can be said that both parties need to adapt to each other to be able to meet their desired needs. What is needed by Mr. Nyoman is the presence of a calm atmosphere during the worship and the maintenance of the the temple in the middle of different communities. While the need of the surrounding community is calmness and peace.

Thus, to fulfill all these needs, both parties made adaptation by socializing and interacting with each other. For example, during the worship held on 15th day of every month in the Pura, the community tries to interact with the Hindus by watching their rituals. Thus, the community has committed adaptation to the presence of Pura amidst their environment. On the other side, the Hindus in Pura, carry out social activities such as helping the construction of roads that involves any community so that it leads to the growth of trust and appreciation from the communities around Pura. Such atmosphere continues to grow within the community which then initiates them to take further actions by helping worship processions both in technical and security matters so that the need for calm and peaceful atmosphere can be fulfilled.

The same thing was also experienced by Pastor Njo Kian Hauw. He is the pastor of the Church of Bethel Indonesia Narwastu and the Head of RT (neighborhood group) since 1997 at 
Merapi Street, Salatiga City. Uniquely, this church is like a house and was licensed by the SKB of 3 Ministers (a joint decree of the Minister of Religion and the Minister of Home Affairs No. 8 and 9 of 2006 on the construction of places of worship) (Kementerian Agama and Kementerian Dalam Negeri 2006). Although obstacles were still found, but the society in general, especially those who are Muslim, tend to accept the presence of the church. The obstacle was even found when asking for approval from other churches. Nevertheless, Pastor Njo Kian Hauw has his own way of establishing relations with the community in the efforts to adapt to the surrounding environment, both the community to the church and vice versa as stated during the interview with him on March 30, 2018.

"For me, on Eid al-Fițr, I do not mobilize my congregation, but I ask the surrounding Christian residents to go with me visiting people who celebrate Eid al-Fițr even though they are Muslim who have never made return visit to us. We ask Christians every year on Eid al-Fițr to visit their Muslim neighbors despite only for a quick shaking hands. I did it from the beginning and I did that before the church was built. I became the head of RT since 1997, so it has been 21 years. I want to compete with Suharto in length of tenure (laughing). So, I always invite the surrounding citizens. It is up to them (Muslim community) to do the same thing or not. The important thing is that we have done a good action.

Do they say Merry Christmas to us? Almost never. This means the RT should be. To my people, I always ask them to go around. In front of us, there are 3 RTs. Right after Takbiran (The eve of Eid al-Fitr), I always go there. They also knew that I wanted to come along so I was told what time and I would go along too. I always ask my residents to visit the Muslims quickly in the morning after the Eid prayer before they go to the tomb or visit their relatives. Meanwhile, the RT in front of us, they usually visit us here in the morning.

By the way, the 3 RTs in the front us usually visit us here (home and church) but never does my RT. In 2005, when I first held the worship agenda on the first day, they visited us in a group 
wearing skullcap from their mosque. I was shocked with their visitation. Since then, they alway come to say merry Christmas. It may be because I always visit them to give congratulation on Eid and now they also do the same on Christmas."

As stated by the pastor Njo Kian Hauw, the relationship and adaptation between Christians and Muslims has been established since 1997 . The way he took is very easy to apply in other social lives, especially during the adaptation process, that is visiting others on the religious holidays. It sounds trivial, but it has a big impact. When a visit is made by individuals or groups who have different backgrounds such as Religion, Race, Tribe and Language, cross cultural communication occurs. When the CCC (Cross Cultural Communication) has taken place, the adaptation process starts to run (Matsumoto 2000). In other words, the process of adaptation would start when people who have different backgrounds connect to each other and talk among them about what makes them different from each other, exchange information about differences, understand the difference, and know what to do with these differences.

We know that interaction and establishing social relations are important keys in the adaptation process. It is exemplified by the value possessed by Mr. Hambali, who is the caregiver of the Rodlotul Huda Boarding School at Bancaan Tengah, Salatiga. He said that migrants who settle especially in Bancaan Tengah area have to adjust to the proverb of ajur-ajer asab-asub ${ }^{4}$. They must adapt to this area which is very plural by socializing and commingling with other people. When the immigrants are eager to minggle with the local people, the surrounding community will automatically love and nurture them to have the same behavior so that they would be accepted by the people around

${ }^{4}$ Ajar-Ajur, Asih-Asuh is a Javanese proverb which means unifying, unified, melting together, and becoming a substance. Asih-Asuh means loving and nurturing. 
them. They are supposed to participate in any social activities. This is a kind of moral-evaluation actions in which a person's behavior should be able to follow the rules or moral values that exist in the surrounding communities. In this regard, the migrants are expected to be able to follow the moral values that exist in Bancaan Tengah community.

However, if the adaptation process does not run very well because it does not fulfill the above actions, a person will face obstacles in meeting his needs. Such case was experienced by Pandu and Henry as college students from Lampung and Papua. They thought that Salatiga is just the same as their home town. For instance, speaking loudly or speaking with high voice at night is considered impolite among Salatiga people but they did it. So, they failed to adapt to social values of the Salatiga society. As a result, small conflicts happened and they got difficulty and even being rejected by the local people when they are looking for a house for rent. Consequently, they could not fulfill their needs in the form of acceptance, security, and comfort while studying in Salatiga. As a result, a bad stigma among the people in Salatiga toward Eastern students is getting stronger. This is also because the community still keep away from the migrants, in the sense that they are still reluctant to socialize with immigrant students so that they do not know the characters of these students.

Actually, in the case of failure in the adaptation process, it is not only experienced by Henry and Pandu as the migrant students from Lampung and Papua, but also by a group of people who wanted to establish a place of worship, in this case, the failure of building a church in an area due to a lack of interaction with the surrounding community. Pastor Njo Kian Hauw said that there were representtaives from a church that consulted to him about this issue. But the presence of the church was still rejected as the Pastor of that church could not minggle with 
the community which eventually led to the rejection and cancellation of the construction of the church located in Bancaan Tengah.

"Several years ago there were people who built a church. Formerly, it was an empty house fo rent. But it then turned into a church and the tenant invited people from outside Salatiga. In fact, this case way improperly executed because the area was actually too small. Besides, there was an empty land next to this building. Why don't they build it there? It was a house, wasn't it?"

The above problem is quite different because it is the problem of licensing abuse even though the community actually accepted the existence of the church. But if we look carefully, this problem is caused by a lack of socialization. This is like a problem which has been told in the previous story and should not cause a big conflict. It proves that the surrounding communities are mature enough to deal with and resolve the conflicts.

From the case above, we can see how important the interaction and socialization by both parties to the new system or their new environment in meeting their needs. In a new system and environment, both of them engage in interaction. In this case, CCU (Cross Cultural Understanding) happens so that both the new system and the existing environment know what methods are needed to fulfill their needs. After the adaptation process, of course, there is a need for Goal Attainment where the system must define and achieve its main objectives. That is, the system is required to get rid of individual thoughts in order to create individual personality in achieving the goals of the system itself (Ritzer 2012). Each system has a goal or plan to be achieved (output), with the conditions if there are resources (inputs) in the form of material, energy, and information. Thus, the system will be able to achieve its goals and can carry out social functions by using existing resources. Therefore, it is necessary to go through a process (throughput) (Deacon and Firebaugh 1988). 


\section{Goal Attainment}

In a diverse communnity, people have goals to be achieved. In the case of the people of Salatiga, they want a peaceful and calm situation. The small conflicts faced by Pandu and Hendry occurred because they were not able to posit themselves in a calm environment and create conditions needed by the community. The problem faced by the church at Bancaan Salatiga was solved with a calm and peaceful process. It shows that the people of Salatiga always want to reach their goals by creating a calm and peaceful condition and try to do anything to achieve it.

They use resources such as information, ethnic, religious, and cultural diversity. In addition to adaptation in order to achieve the desired goal, the goal attainment can be realized through several activities that support or enhance tolerance. Such activities are expected to purify the community's thoughts and then create a tolerant society for the purpose of achieving their goals. By realizing that Indonesia has various religious or customary days, government and the concerned organization are supposed to spread the message of tolerance. At the beginning of the year, in February, there are celebration of Chinese New Year and Cap Gomeh.

"A few years ago, the Tourism Office of City Government in collaboration with Klenteng plans to organize Sinchia event at Jalan Sukowati which causes the closure of the main access to the city. Tents and stands were set up on that road as requested by the Tourism Office. It is very crowded as the people around watched the event. There is also a stage for entertainment. Last year, during Chinese New Year, we do not organize any entertainment programs but private events. This year, in 2018, the Tourism Office cooperates with the Indonesian Chinese Society for Social Unity (PSMTI) plan to organize an entertainment event. The chairman and the committee were at the new office and held an event at GPD building and other events such as Gebyar Sinchia. The committee is a joined committee between the City Government and PSMTI or ordinary citizens. At Jen- 
dral Sudirman Street, there are lanterns set by the PSMTI and the lanterns in front of the temple were made by the Klenteng (temple) itself.

In every Cap Gomeh Festival (a celebration of 15th day or the last day of the Chinese New Year celebration), usually there are gatherings and entertainment, Kendurian, making of Cap Go Meh lontong and it seems that all of these events can only be found in Indonesia. The MUSPIDA (Mayor, Military Resort Office, and Prosecutor's Office) were invited and people from outside or public were also welcome to come. They congratulate each other in the new year, though it is the first time they meet each other in this occasion as it is open to the public. Once, a few years ago, there was a huge event initiated by the church, banks, and the Muslim Chinese group

The other event is Gebyar Sinchia. This big event was organized by a mixed committee of sympathizers, believers, municipal government, and tourism agencies. This event cannot be carried out by the believers themselves as their number is not many. Once, the Salatiga government also held a 2009 tour around the temple by carrying a joint statue using a stretcher and those who joined were 50 temples. While the committee consists of sympathizers and students from Satya Wacana who also came to help."

$\mathrm{Hu}$ Wei Lin as a Kong $\mathrm{Hu} \mathrm{Chu}$ religious leader explained a few things related to Chinese New Year, Cap Gomeh, and King Hoong Ping celebrations during the interview on August 29, 2018. On holidays, there are some festivals such as Sincia, Imlek and Cap Gomeh. The aim of these events is to promote tolerance amid religious and cultural differences in Salatiga City as conducted by the Tourism Office and the City Government of Salatiga in collaboration with Klenteng temple. The government of Salatiga City cooperated not only with the Klenteng but also with the Indonesian Chinese Social Association even with local residents who were willing to join as a committee of the event. The collaboration is carried out during the King Hoong Ping event (prayer for the dead's spirit) and there was also a distribu- 
tion of staple foods for the poor. At a smaller scope, the collaboration is made with the Village and heads of RT and RW for data collection of underprivileged residents in every 8 Villages in Salatiga City.

Through these activities, it is expected that difference is not an obstacle to love fellow human beings, so that any barrier coming from different religion and culture that exists in the community would disappear. When these barriers disappear, automatically the community will be willing to accept the differences in their social life regardless of any bad stigma. Without considering the bad stigma and accepting the difference means you have reached the point of tolerance. When the tolerance is achieved, the main goal is to create a safe and peaceful condition.

Another collaboration to improve tolerance was also carried out by GKJ (Javanese Christian Church) Sidomukti Salatiga in cooperation with Student Choir of IAIN Salatiga. In the 2018 Easter celebration, Student Choir of IAIN Salatiga contributed the song "day by day" during the 2018 Easter celebration at GKJ Sidomukti. As explained by Mr. Eben as the chairman of the celebration and GKJ pastor on April 4, 2018, the celebration of the Easter held in the Javanese Christian Church of Sidomukti is an implementation of the Easter theme that is tolerance. In fact, activities and cooperation related to tolerance and pluralism have been built for a long time. For that reason, the GKJ initiated to collaborate with IAIN students in the celebration of Easter as a form of tolerance that has a unique message for the Salatiga community. The Easter Feast that invited choirs of IAIN students is a process (throughput) of achieving the Goal Attainment (Output), that is the creation of tolerance for the realization of a peaceful, safe, and comfortable environment using existing resources (input) such as the diversity of the environment itself through the relationship that was established be- 
tween GKJ Sidomukti in cooperation with IAIN Salatiga or with Sonat Muda or with other NGOs, and existing human resources (students, related parties, congregations).

Nonetheless, in the process of achieving the Goal Attainment, there were many pros and cons addressed to this activity. The pros came from people who already understood and had tolerance attitude so that they appreciated these activities in order to increase tolerance. However, the people who disagreed with both the Christians and the Muslims still had negative thingking regarding the activity carried out by the GKJ and Student Choir (IWM). The Christians who opposed this idea questioned the invitation of choir team from different belief, and not from the church youths. In addition, another reason is that the organization of the activity might invite various problems. For the Muslim community, it could disrupt their faith and the wider community because they have entered the church and sang Christian songs.

In the process of achieving the Goal Attainment, GKJ and IAIN only wanted the wider community to see that the involvement of the IAIN choir team was a form of tolerance and peace even though they are from different belief, they still could make a festive event. On the contrary, the opposing community assumed that the song sang by IAIN students would disrupt their faith. In fact, the song "day by day" is a Gospel song composed in 1971 by Stephen Schwartz and John-Michael, which the lyrics have no praising meanings such as in Spiritual songs in general, but statements or prayers to be more truly committed to faith and more intimate in communicating with God.

The Easter celebration and the improvement and implementation of tolerance were still continuing. As a tradition, the celebration of Easter and other holidays were also held in the Pancasila square in Salatiga. The unique of this square is the 
existence of the Great Mosque located at the west of the square, which was being the backdrop for the Easter celebration. The 2018 Easter celebration began at 8:00 p.m. after Isya prayer and after the celebration of Easter Service at every church until the end of the Easter celebration at the Pancasila square at 10:00 p.m. Importantly, all elements of CSOs, NU Banser, Youth NGOs, and all related parties participated in the safeguarding of the 2018 Easter celebration to achieve Goal Attainment by creating peaceful, safe, and calm conditions. However, some obstacles were still found in achieving the goal attainment as explained by Mr. Adi during the interview conducted on August 25, 2018 at the Santa Paulus Miki Catholic Church in Salatiga.

"We found problems a few years ago. There was an attempt to mess the Easter celebration at Pancasila square. BKGS agreed to hold the celebration along with wayang wong performance and it would be performed in the afternoon. We prepared everything since the morning, but there was another activity held earlier that was morning prayer. Pamphlets were spread to publish the activity and written on it 'let's pray together at dawn'. Our event was finally canceled. In fact, there were about 100 people coming to the mosque and it was guarded by the military."

Allegedly, Islamic Defender Front (FPI) planned to thwart the event. FPI has been harshly rejected in Semarang and then came to Salatiga and again rejected. At that time, Regional Leadership Communication Forum (Forkopimda) Salatiga gathered its members and made a joint statement "We are as the citizens of Salatiga City refuse the presence of FPI and all kinds of radicalism and fundamentalism teachings". It was attended by Military and Police officers which then they took photo together with posters and published in the mass media. Further they said, "We are as religious figures see that such action is considered the act of radicalism." I do not want any chaos or conflicts happen at the grassroots." 
GKJ Sidomukti and IAIN choir team also faced the same obstacle in achieving the goal attainment though it is quite different that is a group of people threatened the entire church community that would celebrate Easter Feast at the Pancasila Square. Of course, there was a decisive actions against the group, FPI (Islamic Defender Front), that threatened the people of Salatiga to achieve their Goal. Prevention of that intolerant action was carried out by the Forkopimda. The difference is that it was conducted softly and different from that carried out by other cities, especially Semarang City. Although the obstacles and efforts to prevent Goal Attainment continued to occur, it will not reduce the enthusiasm of the people in spreading tolerance to achieve a common goal.

At the Galunggungan and Kuningan celebrations, the Muslim and Christian youth also took part and enlivened the event by coming and watching it and this encouraged the Pura (Hindu) to also secure other religious celebrations as a form of appreciation and to increase tolerance attitude so that the Goal Attainment could be achieved. While for the Muslims before celebrating Eid al-Fițr, they are undergoing one month fasting ritual in Ramadan. During this time, there are also many events that represent the attitudes of tolerance. One of them is the distribution of takjils conducted by the congregations and youth of the Saint Paulus Miki Catholic Church, Salatiga City. The distribution of takjil has been running for three years. Takjil is collected voluntarily from the congregations who want to contribute. The distribution of takjil usually starts at 2:00 p.m. and finishes at 5:30 p.m. The target of takjil distribution is passing motorists, surrounding communities, Pedicab drivers, parking attendants or security guards. Jody as the chairman of the joint committee of Paulus Miki Church youths hopes that such volun-

\footnotetext{
${ }^{5}$ Light snacks to break the fast.
} 
tary activity can give the same message to our friends from IAIN and motivate them to spread the seeds of tolerance so that the goal of creating a safe, calm, and peaceful environment could always be achieved.

The same activity was also conducted by BKGS, Churches Unity Body of Salatiga, that cooperated with all churches in Salatiga by delegating their youths to assist in guarding the security during Eid al-Fițr prayer held in the Pancasila square. The preparation has been started 3 days before the event. The youths and old participated in taking care of security. Similar security guard was also undertaken during 2018 Christmas celebration and 2018 Easter celebration. But 2018 Christmas celebration was attended by more congregations than those who attended the Easter celebration. Therefore, it involved many elements such as Polices, Banser NU, Indonesian Red Cross (PMI), Satpol Pamong Praja, Military, and even Scouts to secure the 2018 Christmas celebration. All elements of the society consolidated during the 2018 Christmas celebration in order to achieve the goals by increasing the value of tolerance regardless of their social background and identity.

The 2018 Christmas celebration started at 04.00 a.m. after the call of prayer in mosques. The agenda began with a speech from the chairman of the committee and the chairman of the BKGS accompanied by the praise song of Holy Night then continued with the Christmas service. "Jesus Christ Wisdom for Us" became the topic of the Christmas celebration this time. And there were a series of events before the Christmas service held on December 25, 2018, namely the Christmas Parade which was held on December 22, 2018. Christmas Parade is a parade to greet the coming of Christmas. The parade was participated by all churches elements throughout Salatiga, including Christian and Catholic Schools from kindergarten level to high school 
level, Salatiga Cluster PPA, Theological High Schools, and Satya Wacana Christian University. The Christmas parade chose the theme "Tolerance in Diversity" where this parade not only aimed to celebrate Christmas, but also gave a message to the community to increase tolerance and respect the diversity in Salatiga so that the desired goal of a safe, peaceful, and calm environment can be achieved.

The convoy of the Salatiga Christmas Parade itself consisted of the Patrol Car, the motorcycle community, Red and White Flags, BKGS flags and members of the BKGS Churches, Batik Carnival, the participants of parade and the last was the cleaning broom squads. The event was quite crowded, witnessed by all the Salatiga people who passed by and enlivened by all elements of the Salatiga community regardless of their different social backgrounds. The convoy started at 10:00 a.m. and finished at 1:00 p.m. at the Pancasila square. Parson said that the goal attainment in a system can be measured by the quality and performance of the goals. Goal attainment that is based on quality can be measured from the values obtained from achieving goals, usually in the form of satisfaction and appreciation of something that has been achieved. Goal attainment that is based on performance can be measured based on something that can be shown in action (Parsons 1953, as cited by Hamilton 1983).

According to Parsons, achieved goals can be seen from the quality of the process itself and the success or failure of the process in achieving goals can be seen from the actions produced. To achieve the goal of creating a safe and peaceful environment, a lot of efforts have been done so that the people of Salatiga become very tolerant amid the diversity of this city. Although in the process of achieving goals are found some obstacles as experienced by GKJ Sidomukti, IAIN students and BKGS, it did not dismiss their enthusiasm in continuing to spread tolerance 
to achieve the goals. By promoting diversity that exists in this city through celebration of religious holidays that involves different groups, it will make the Salatiga community more mature in their attitude towards differences. This mature attitude will bring to the desired goals. Any negative thinking or suspicion due to lack of openness to differences is expected to be eradicated by continuously promoting the beauty of diversity through collaborative events between different groups in religious celebrations.

In AGIL's analysis, another important element is Integration. Integration refers to the maintenance of bond and solidarity, by involving these two elements in controlling, maintaining subsystems, and preventing major disturbances in the system. Integration in a system is important for the continuity of the system because integration involves the four AGIL variables. All these four variables must strengthen one another so that all members of the system can persist in their environment (Hamilton 1983).

\section{Integration}

It can be said that integration is a regulator of the relationship of the parts that become its components. In this case, the integration between individuals or groups with others that have different backgrounds such as Religion, Race, and Tribe must establish good relationship. Integration must be realized to ensure that there is an emotional bond within the social system to produce solidarity and willingness to work together. In other words, integration must maintain the relationship between the other three elements (adaptation, goal attainment, and latency). The involvement of various elements in Salatiga such as the Government, NGOs/CSOs, religious leaders and the wider community in joint activities is expected to strengthen tolerance in Salatiga.

One of the collaborations was carried out by Percik, an NGO that is vigorously voicing the spread of love, peace, and toler- 
ance. In this regard, Percik cooperated with the government in the effort to control tolerance existing in the community by creating activities aimed at maintaining adaptation, where people can adapt to a pluralistic environment. It is also goal attainment so that the community can achieve the desired goals by utilizing existing resources, as well as latency where the community who has achieved the desired goals can maintain the achieved system. Goal Attainment can be seen from the number of people who support and help the process of religious celebrations or those who accept the differences which could create conditions for the realization of calm, peaceful, and safe atmosphere.

Like in the case of FPI refusal as they wanted to make trouble in the Easter and Christmas celebration, the synergy between Forkopimda, FKUB, and CSOs and the community at that time was necessary to maintain and control the other existing components (adaptation, goal attainment, and lateny) because they would thwart a component of goal attainment. The synergy in managing and preserving the existing components was also carried out by Bakesbangpol as its main tasks and functions is to provide guidance to social organizations such as FKUB, Students, Rukun Tetangga, Rukun Warga, Youth Organizations, College Students, Political and Religious Organizations. Besides, Bakesbangpol also has a function as a place for consultation for mass organization. As stated by Mr. Purwanto that every NGO or CSO will get a help in the implementation or design their program. This is also an example of synergy between the government and its CSOs or NGOs.

When all elements have been achieved, Latency or maintenance of the existing system needs to be done. The system must complete, maintain, and renew individual motivation and cultural patterns that create and maintain that motivation. System maintenance (latency) refers to the process by which compulsive 
energy is stored and distributed in the system, involving two interrelated problems namely the pattern of maintenance and management of problems or tensions (Hamilton 1983).

\section{Latency (Maintenance)}

In the case of Latency, many CSOs or NGOs offer a variety of programs that refer to the maintenance of tolerance to create a safe, peaceful, and conducive environment.. In this case, we could take a look at Percik, an NGO which concerns on religious freedom, human rights and the spread of love in diversity. Percik realizes that the diversity potential possessed by Salatiga City must be maintained. The long lasting diversity and harmony which has been achieved through several activities and breakthroughs that make people more aware of the importance of tolerance urge Percik to contribute more in maintaining tolerance behavior. Through various kinds of activities and small organizations established by Percik consisting of people who have different backgrounds and people who are very concerned about tolerance, Percik has provided stimulus for promoting tolerance values through small organizations such as SOBAT, Kata Hawa, and Cross faith.

One of Percik's activities in preserving diversity is the crossfaith camp. As stated by Ambar, the staff member of Percik, this event is aimed to eliminate barriers among the youths. Through this event, it is expected that the existing barriers can be eliminated and in turn will create a higher sense of tolerance. When they face intolerant acts, they can stand firmly to maintain the tolerant attitude which they believe that it is the right thing to do because they really feel the beauty of diversity through interfaith camp activities. It is hoped that they can spread tolerant attitudes to other individuals who have not yet known the beauty of tolerant attitudes or to enrich individual beliefs about the beauty of tolerance. 
In the effort of preserving motivation so that the individuals behave tolerantly to maintain the established system, the system must be able to involve two interrelated problems namely the pattern of maintenance and management of problems or tensions. In the maintenance process, the system must also be able to manage problems or tension so that motivation is maintained. The problem in this case, for instance, the suicide bombings that exploded few months ago in two churches in Surabaya. Of course, this tragedy has made anybody especially those who live in Salatiga felt shaken. The occurrence of this unintended incident can disrupt the existing peaceful atmosphere as it caused suspicion, disbelief, and judgment.

Therefore, on Monday, 14 May 2018, a solidarity action against terrorism was carried out by various elements of society who gathered at the roundabout of Salatiga City by carrying candles and praying together from various religions. Similar action was also conducted by the Church of Paulus Miki which was supported by various parties such as regional governments and NGOs, one of them is Percik and Sobat Muda. From the organization of this action, hopefully the community will be more sensitive about the importance of maintaining tolerance and they are not supposed to be afraid of the threats of terrorism that may come anytime. The other activities organized by Percik to maintain and improve tolerance and diversity among others are interfaith dialogue and fast-breaking together held in the fasting month of Ramadan in 2018. On this occasion, Percik cooperated with the youths of the Church of Santo Paulus Miki Salatiga. Actually, this is a series event of takjil distribution. The participants of the interfaith dialogue were not only the youths of Salatiga but also the youths from Semarang and surrounding areas. The event brought up the topic "Sila-Turah-Mi Mendobrak Nurani Kebangsaan (the Friendship to Strengthen National Conscience)". The effort of maintaining and increasing moti- 
vation for the realization of tolerance does not cease here. Last year, in November, Percik, as one of the pioneers in promoting tolerance, held a series of events to commemorate the world tolerance day which falls on November 16, 2018.

Indeed, in the process of latency or maintenance, the system must also be able to deal with latent symptoms in the community. This maintenance must also be supported by all elements in the system. If it does not go well, the system will not run smoothly, which makes it difficult for adaptation and results in bias in achieving the common goals. If the goal is not achieved, integration is then difficult to be done and the latency will be difficult to be executed. , The maintenance or latency sounds trivial, but this is actually the most difficult part because there will be many obstacles ahead that will try to attack the system.

\section{Discussion}

Reflections on this research focusing on "Harmonizing the Society in the Middle of Diversity in the City of Salatiga" using the analysis tool of A.G.I.L Talcott Parsons. However, this is not the first research that focuses on diversity or tolerance. There are several factors and focuses that make this study different from previous research. For example, a study conducted by Jennifer Bambang Yusuf Purba (Purba 2015) entitled "Peace in Religious Diversity in Pamatang Sidamanik Village (a Study of Factors Affecting Communities in Pamatang Sidamaik Village Who Remain in Harmony in the Midst of Religion Diversity)". The findings in the study found that factors influencing the creation of peace were due to the existence of Christianity and Islam that taught to love one another in the midst of differences that existed and were upheld by citizens. In addition, Suhur's family and Sapangahapan's family attitude is also highly respected. Besides, the exixtence of Habonaron Do Bona and Tolu Sahundulan philosophies has become the guiding principle of life. 
Although focusing on the same topic and using the same method but this study are different from the previous ones. One of the differences is the location of study, in which Jenifer's study is located in Pamatang Sidamanik while this study is located in Salatiga City. Another difference is how a study analyzes the community. In Jeniffer's study, she used theological point of view as analysis tool by which harmonization was found because people believe in the dogma written on the scriptures concerning harmonization. While, in this study, the analysis tool is the functional structure to see how the community adapts, achieves goals, integrates, and maintains what has been achieved amid the differences.

Ardi Utama (2015) in his study entitled "The Relationship between the Level of Religiosity and Religious Tolerance in Salatiga" using quantitative method explains that there is no relation between the level of religiosity and tolerance. It is possible that religious tolerance is influenced by other factors such as phases of adjustment and meeting among religions, development of faith, fundamental religion and education. The results of the research conducted by Ardi show that there is no correlation between faith and tolerance in Salatiga. He uses quantitative approach, whereas in this study do the authors use qualitative approach. Concisely, Ardi's research has not been able to obtain more information from the informants because it uses simple questionnaire, while this study can gain more information because it uses a deep interview.

The results of this study are similar to those conducted by David Samiyono (2011). His study entitled "Pluralism and Conflict Management" showed that strong diversity and theological exclusiveness should not be seen as a source of problems. Instead, it shows the importance of overcoming polarization and the necessity for efforts from government to build and develop 
pluralism in the community. David's study focuses on conflict management and he believes that conflict can be mitigated by efforts made by the government to build and develop pluralism. However, the AGIL's theory proposed by Parsons epxlains that to manage conflict and develop pluralism, all elements of society must be involved. It would be a useless effort if only the government that strives for developing pluralism and not supported by any other element of the society.

\section{Conclusion}

From the results of this research on the Community Harmonization Amidst the Diversity in Salatiga City with a sociological perspective, , the authors conclude: in the realization of tolerance, the role of government is needed in the matter of making policies that are not discriminative and in encouraging and enhancing tolerance behavior. From the point of view of AGIL, the adaptation process only occurs by one party, namely a system that must adapt to its environment in order to meet its needs. But in fact, adaptation is also carried out by two parties. It means that the environment must also adapt to the new system that comes in its environment. For example, immigrant students who have different ethnic, racial, and religious backgrounds are accepted in communities. Socialization and interaction are the keys of success in adaptation, either a system that must adapt to the environment or vice versa, so that both parties can meet their needs.

In the process of goal attainment, the system must also be prepared for all kinds of obstacles and rejections in pursing the minds of individuals to behave in a tolerant manner so that the goals can be achieved, then the system can prepare ways to achieve the desired goals more mature. Integration is the key element in the AGIL analysis. Synergy from various parties, from the Government, CSOs or NGOs, and the Community in estab- 
lishing relationships is necesssarily to be strengthened. Without strong integration, it is very difficult to carry out other functional imperatives. While the element of latency in maintaining a tolerant environment so that a peaceful and calm conditions can be realized needs to be preserved consistently, considering that there will be many problems or obstacles that will come to break the system that has been already established. Therefore, various activities and appreciation in increasing and maintaining tolerance are needed. In the process of latency (maintenance), all parties from the Government, NGOs or CSOs, and the community need to be involved in maintaining of what has been achieved.

\section{Bibliography}

Deacon, Ruth E., and Francille M. Firebaugh. 1988. Family Resource Management: Principles and Applications. Boston, MA: Allyn and Bacon.

Faridah, Ika Fatmawati. 2013. "Toleransi Antar Umat Beragama Masyarakat Perumahan.” Jurnal Komunitas 5 (1): 14-25.

Gumilang, Prima. 2017. "Hantu Aksi Intoleran Di Tahun Ayam Api.” CNN Indonesia. 2017.

Hamilton, Peter. 1983. Talcott Parsons (Key Sociologist). 10th ed. London: Routledge.

Haryanto, Joko Tri. 2012. "Interaksi Dan Harmoni Umat Agama." Walisongo: Jurnal Penelitian Sosial Keagamaan 20 (1): 211-34.

Hermawati, Rina, Caroline Paskarina, and Nunung Runiawati. 2017. "Toleransi Antar Umat Beragama Di Kota Bandung." Indonesian Journal of Anthropology 1 (2). https:// doi.org/10.24198/umbara.v1i2.10341.

Kementerian Agama, and Kementerian Dalam Negeri. 2006. Peraturan Bersama Menteri Agama Dan Menteri Dalam Negeri Nomor: 9 Tahun 2006 Nomor: 8 Tabun 2006 Ten- 
tang Pedoman Pelaksnaaan Tugas Kepala Daerah/Wakil Kepala Daerah Dalam Pemeliharaan Kerukunan Umat Beragama, Pemberdayaan Forum Kerukunan Umat Beragama. Indonesia.

Kesbangpol Salatiga. 2017. "Kegiatan Halaqoh Badan Kesbangpol Kota Salatiga Tahun 2017.” Salatiga: Badan Kesatauan Bangsa dan Politik Kota Salatiga.

Matsumoto, David. 2000. "Diffrence Beetwen Cross-Inter and Intra Communication." Encyclopedia Of Psycology Amarican Psycological Assosiation 2: 35-359.

Munawwir, Ahmad Warson. 2002. Al-Munawwir: Kamus Arab-Indonesia. Edited by Ali Ma'shum Munawwir and Zainal Abidin. 2nd ed. Surabaya: Pustaka Progressif.

Mutiara, Kholidia Efining. 2017. “Menanamkan Toleransi Multi Agama Sebagai Payung Anti Radikalisme: Studi Kasus Komunitas Lintas Agama Dan Kepercayaan Di Pantura Tali Akrab." Fikrah 4 (2): 293. https://doi.org/10.21043/fikrah. v4i2.2083.

Purba, Jenniffer Bambang Yusuf. 2015. "Perdamaian Dalam Keberagaman Agama Di Desa Pamatang Sidamanik.” Universitas Kristen Satya Wacana.

Ritzer, George. 2008. Teori Sosiologi Modern George Ritzer Dan Douglas J. Goodman. Edited by Tri Wibowo Budi Santoso. Jakarta: Kencana Predana Media Group.

. 2012. Teori Sosiologi: Dari Sosiologi Klasik Sampai Perkembangan Terakhir Postmodern. 8th ed. Jakarta: Pustaka Pelajar.

- 2014. Teori Sosiologi Modern. Edited by Douglas J. Goodman. Jakarta: Kencana Predana Media Group.

Samiyono, David. 2011. "Pluralisme Dan Pengelolaan Konflik." Lokakarya "Membangun Perdamaian Di Dalam Masyarakat Ber-Bhineka Tunggal Ika." Salatiga. 
ANDIKA DWIARTA PUTRA ET AL.

Setara. 2018. “Indeks Kota Toleran (IKT) Tahun 2018." Setara Institute. Jakarta.

Utama, Ardi. 2015. "Hubungan Antara Tingkat Religiusitas Dengan Toleransi Agama Di Salatiga.” Tugas Akhir Fakultas Psikologi Guna Memenuhi Sebagian Dari Persyaratan Untuk Mencapai Gelar Sarjana Psikologi. 